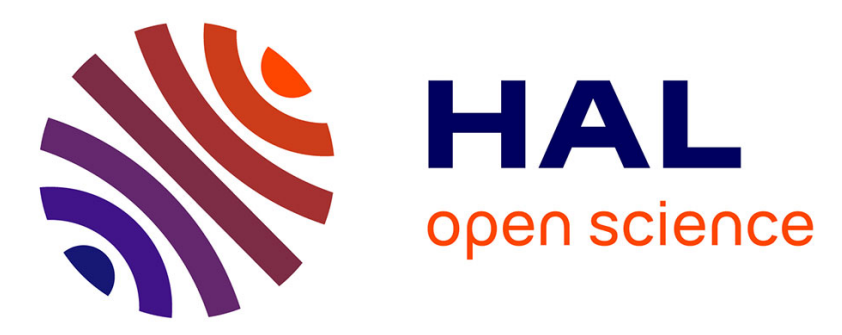

\title{
Biophysical dependences among functional wood traits
} Jana Dlouha, Tancrède Alméras, Jacques Beauchêne, Bruno Clair, Meriem Fournier

\section{To cite this version:}

Jana Dlouha, Tancrède Alméras, Jacques Beauchêne, Bruno Clair, Meriem Fournier. Biophysical dependences among functional wood traits. Functional Ecology, 2018, 32 (12), pp.2652-2665. 10.1111/1365-2435.13209 . hal-01897771

\section{HAL Id: hal-01897771 https://hal.science/hal-01897771}

Submitted on 17 Oct 2018

HAL is a multi-disciplinary open access archive for the deposit and dissemination of scientific research documents, whether they are published or not. The documents may come from teaching and research institutions in France or abroad, or from public or private research centers.
L'archive ouverte pluridisciplinaire HAL, est destinée au dépôt et à la diffusion de documents scientifiques de niveau recherche, publiés ou non, émanant des établissements d'enseignement et de recherche français ou étrangers, des laboratoires publics ou privés. 


\title{
Biophysical dependences among functional wood traits
}

\author{
Jana Dlouhá ${ }^{1}$ (I) | Tancrède Alméras ${ }^{2}$ | Jacques Beauchêne ${ }^{3}$ | Bruno Clair $^{2,4}$ | \\ Meriem Fournier $^{1}$
}

\author{
${ }^{1}$ Université de Lorraine, AgroParisTech, Inra, \\ Silva, Nancy, France \\ ${ }^{2}$ LMGC, CNRS, Université de Montpellier, \\ Montpellier, France \\ ${ }^{3}$ CIRAD, UMR EcoFoG, AgroParisTech, \\ CNRS, INRA, Université des Antilles, \\ Université de Guyane, Kourou, France \\ ${ }^{4}$ CNRS, UMR EcoFoG, AgroParisTech, Cirad, \\ INRA, Université des Antilles, Université de \\ Guyane, Kourou, France \\ Correspondence \\ Jana Dlouhá \\ Email: jana.dlouha@inra.fr \\ Funding information \\ French National Research Agency to the \\ Woodiversity, Grant/Award Number: \\ ANR-05-BDIV-0012-04; Bridge, Grant/ \\ Award Number: ANR-06-BDIV-0004; \\ French National Research Agency \\ (ANR), Grant/Award Number: ANR-11- \\ LABX-0002-01 and ANR-10-LABX-25-01
}

\begin{abstract}
1. Wood properties and especially wood density have been used as functional traits organized along major axes of species life history and strategy. Beyond statistical analyses, a better mechanistic understanding of relationships among wood traits is essential for ecologically relevant interpretation of wood trait variations.

2. A set of theoretical relationships mechanistically linking wood basic density with some other wood traits is derived from cellular material physics. These theoretical models picture basic physical constraints and thus provide null hypotheses for further ecological studies. Analysis is applied to data from two original datasets and several datasets extracted from the literature.

3. Results emphasize the strong physical constraint behind the link between basic density and maximal storable water on the one hand, and elastic modulus on the other hand. Beyond these basic physical constraints, the developed framework reveals physically less expected trends: the amount of free water available for physiological needs increases in less dense wood of fast-growing species, and the cell wall stiffness decreases with density in temperate hardwoods and is higher in sapling stages in the rainforest understorey where competition for light is associated with high mechanical risk.

4. We emphasize the use of theoretically independent traits derived from models of cellular material physics to investigate the functional variation of wood traits together with their environmental and phylogenetic variations. Although the current study is limited to basic density, green wood lumen saturation and wood specific modulus, we further emphasize the identification of complementary independent wood traits representing other biomechanical functions, nutrient storage, hydraulic conductance and resistance to drought.
\end{abstract}

\section{KEYWORDS}

basic density, biomechanical traits, hydraulic traits, wood traits

\section{1 | INTRODUCTION}

The integration of wood traits as an independent variation axis orthogonal to leaf traits has been emphasized in plant ecology (Baraloto, Timothy Paine, et al., 2010; Chave et al., 2009; Fortunel, Fine, \& Baraloto, 2012; Richardson et al., 2013). Wood density is often taken as a key functional wood trait. Species with high density tend to have lower growth and mortality rates, increased adult stature, shade tolerance and drought resistance (King, Davies, Tan, \& Noor, 2006; Kunstler et al., 2016; Osazuwa-Peters, Wright, \& Zanne, 2017; Osunkoya et al., 2007; Poorter et al., 2010). However, evidence for wood density as a proxy of species strategies is mixed (Moles, 
2018; Russo et al., 2010). Indeed, to get relevant functional wood traits, tissue properties must be integrated at the whole plant level taking into account volume and shape of woody organs (Fournier, Dlouha, Jaouen, \& Almeras, 2013; Lachenbruch \& McCulloh, 2014). Moreover, as woods with the same density can have different anatomies and cell wall structure, hydraulic and mechanical properties can be poorly linked to wood density (Lachenbruch \& McCulloh, 2014; Zanne et al., 2010; Ziemińska, Westoby, \& Wright, 2015). As developed by Zanne et al. (2010) for hydraulic conductivity, more complex metrics of orthogonal axes of wood traits can be designed beyond the main axis of wood density. Lastly, dealing with wood density or other wood traits, attention must be paid to wood water content. Basic density, that is, the ratio between dried biomass to wet volume of wood in living trees, is nowadays a widely measured variable, used to estimate biomass and carbon fluxes from wood volumes assessed from non-destructive forest measurements (Bastin et al., 2015; Chave et al., 2009; Nogueira, Fearnside, \& Nelson, 2008). Beyond basic density, green wood density (including water content of wood in the living tree) is functionally relevant-for example, it represents the mechanical load per unit of stem volume-and is statistically well correlated to other wood traits (e.g., Niklas \& Spatz, 2010). Beyond this rough correlation, more independent and functionally relevant traits, as water content, can be calculated from basic and green density (Gartner, Moore, \& Gardiner, 2004; Poorter, 2008).

In this paper, we emphasize physical constraints contained in empirical correlations between some wood traits. Indeed, correlation and causation are complex problems for the science of plant traits (Westoby \& Wright, 2006). For evolutionary biologists, physical relationships cannot be disentangled from biological ones as evolution operates on the basis of a set of developmental constraints that are "physical" (in the sense that they fulfil mechanical or physiological functions). However, some physical relationships-as, for example, "the higher the density, the lower the porosity in the cellular material"-are biologically meaningless. There is no need of a complex genetic system to insure the co-evolution of density and porosity which is an intrinsic property of cellular materials, biological or artificial (Gibson \& Ashby, 1997). Therefore, such laws of physics (most of them are less intuitive than the link between density and porosity) provide null hypotheses to ecologists. Then, analysing empirical statistical discrepancies from these null hypotheses, so long as they are not the result of measurement error, are meaningful in terms of adaptation to environmental conditions and/or phylogenetic constraints. Note that these meaningful discrepancies can be poor correlations, although they would have been assumed as poor results by empirical science. The mechanistic toolbox we will develop uses a simplified representation of wood as a cellular material (Gibson \& Ashby, 1997) to derive a set of physical relationships expected to link wood density measured at different moisture contents with some functional wood properties. We focus on the following properties: the potential capacitance of wood tissue, that is, the maximum amount of water that can be stored in a given wood volume, and the complementary amount of gas stored, already used by Gartner et al. (2004) or Poorter (2008) as functional traits, and the elastic modulus, that is, the tissue mechanical stiffness, a relevant and basic biomechanical trait (Niklas \& Spatz, 2012). Two original datasets of wood properties will be used. Dataset 1 is part of a large research project (Baraloto, Paine, et al., 2010; Sarmiento et al., 2011), includes a large diversity of species and contains basic density, green density and saturated density data. Dataset 2 provides data about inter- and intraspecific variability of basic density and elastic modulus of wood from trees at sapling stages where mechanical stability is a great constraint.

In this paper, we will check null hypothesis stressed in the physical model of relationships among wood traits. Dataset 1 comes from a zone without a drought constraint so we do not expect any discrepancy from null hypotheses linking wood water content and construction cost, supporting results of Baraloto, Paine, et al., 2010; Baraloto, Timothy Paine, et al., 2010 who described one main axis of stem strategy: dense wood vs. high wood water content. In dataset 2, we could expect that to maintain self-support, the lower wood density of fast-growing pioneer species is compensated by higher cell wall stiffness, so that the relationship between wood density and modulus of elasticity differs from the null hypothesis.

\section{MATERIALS AND METHODS}

\section{1 | Plant material}

Wood material for dataset 1 was collected in seven permanent 1ha plots in French Guiana between November 2007 and September 2008. Overall, 2234 wood specimens from 601 species (http:// bridge.ecofog.gf/) were collected from adult trees, each species being represented by at least one tree without any within-tree repetition of specimens. A 7-mm-diameter increment borer was used to extract sapwood at $1.3 \mathrm{~m}$ above-ground level. Bark and cambium tissues were removed manually from each core to obtain a representative 6-mm-long core containing only sapwood. The specimens were placed in a $2-\mathrm{ml}$ plastic tube, stored at $-20^{\circ} \mathrm{C}$ in a portable freezer in the field and transported to a laboratory at Kourou, French Guiana, for density measurements.

Wood material for dataset 2 was collected at the Paracou Research Station, French Guiana ( $5^{\circ} 18^{\prime} \mathrm{N}, 52^{\circ} 55^{\prime} \mathrm{W}$; Gourlet-Fleury, Guehl, \& Laroussinie, 2004), between September 2006 and October 2007. Ten tree species were selected among common angiosperms to cover a wide range of wood density. A total of 528 wood specimens were taken from saplings with diameter at breast height ranging from 40 to $70 \mathrm{~mm}$ including several replicates per tree to capture the wood properties' radial variation. Straight as well as leaning stems were included in the study. Specimens $(150 \times 12 \times 2 \mathrm{~mm}, \mathrm{~L} \times \mathrm{T} \times \mathrm{R})$ were cut along the grain from $50-\mathrm{cm}$-long basal logs within a week after felling the trees at various distances from the pith including the juvenility gradient usually associated with strong radial variation in wood structure and properties (Lachenbruch, Moore, \& Evans, 2011). In tilted trees, sampling was performed along the diameter with higher eccentricity expecting occurrence of reaction wood (Ruelle, Clair, Beauchene, Prevost, \& Fournier, 2006). The objective was to maximize the intraspecific variability in 


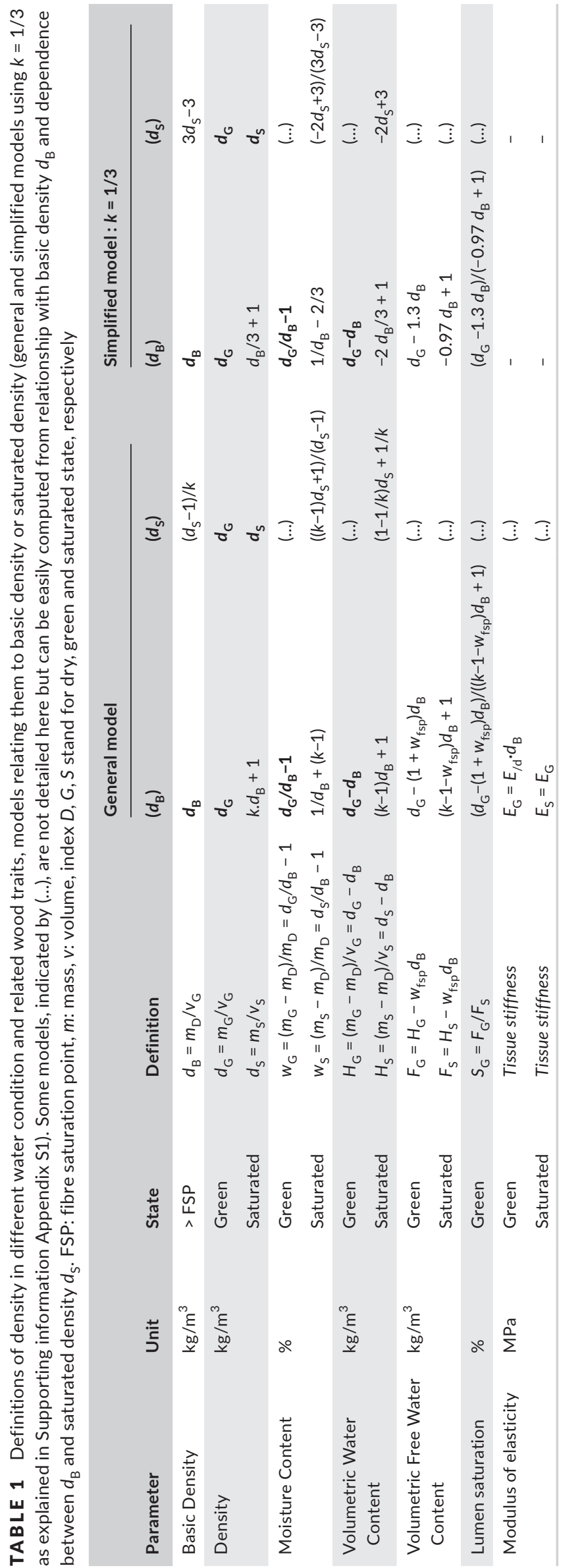

terms of different wood types (juvenile, tension and opposite wood). Specimens were then wrapped in wet sheets and plastic bags for transport from the field to the laboratory and kept wet immersed in water at low temperatures $\left(4 \pm 0.5^{\circ} \mathrm{C}\right)$ to avoid degradation (Dlouha, Almeras, \& Clair, 2012). Both datasets are available in the Dryad Digital Repository (Dlouhá, Alméras, Beauchêne, Clair, \& Fournier, 2018)

\subsection{Mass and volume measurements}

For both datasets, the mass of specimens was measured in green state, and their fresh volume was estimated by the double weighing method (Barnett \& Jeronimidis, 2003). For dataset 1, specimens were then saturated in water in vacuum condition during $48-72 \mathrm{hr}$ and finally dried at $103^{\circ}$ for $72 \mathrm{~h}$. Specimens of dataset 2 were dried at $60^{\circ} \mathrm{C}$ for $48 \mathrm{~h}$ which results in residual moisture content of $0.75 \% \pm 0.03 \%$ (Brémaud, 2006) but avoids micro-cracks during the drying so that specimens remain suitable for mechanical testing. Density and moisture content were calculated according to relationships and are summarized in Table 1.

\section{3 | Elastic modulus}

The elastic modulus for dataset 2 was estimated by forced flexural vibration method on specimens in green condition within 1 month after felling the tree. A frequency sweep detects the resonance frequency, from which the specific modulus of elasticity $\left(E_{/ d}\right)$ is determined according to the Euler-Bernoulli equation:

$$
E_{/ d}=\frac{48 \pi^{2} l^{4} f^{2}}{m^{2} h^{2}},
$$

where $I$ and $h$ are the specimen length and thickness, $f$ is the resonance frequency of the first mode and $m$ is a constant depending on mode order $\left(m_{1}=4.730\right)$. Details on the experimental procedure are given in Brémaud et al. (2012).

\subsection{Definitions of traits and physical relationships between traits}

Definitions of different wood traits are summarized in Table 1. Physical assumptions and laws, detailed in Supporting information Appendix S1, give expected relationships among these traits. Results of calculations can be synthesized as follows (see also Table 1):

Above the fibre saturation point (FSP), moisture content $w_{\mathrm{G}}$ links basic density $d_{\mathrm{B}}$ with green density $d_{\mathrm{G}}$ :

$$
w_{G}=d_{G} / d_{B}-1
$$

The dependence of saturated density $d_{\mathrm{S}}$ on basic density $d_{\mathrm{B}}$ is linear:

$$
d_{\mathrm{S}}=1+k d_{\mathrm{B}}
$$

The intercept equal to 1 means that when basic density tends to 0 , wood saturated density comes close to the density of water. 
The parameter $k$ is $1 / 3$ according to a simplified model assuming the additivity of volumes.

Maximum moisture content $w_{\mathrm{S}}$ and basic or saturated density are then linked as follows:

$$
\begin{gathered}
w_{\mathrm{S}}=1 / d_{\mathrm{B}}+(k-1) \approx 1 / d_{\mathrm{B}}-2 / 3 . \\
\mathrm{W}_{\mathrm{S}}=\left((k-1) d_{\mathrm{S}}+1\right) /\left(d_{\mathrm{S}}-1\right) \approx\left(-2 \cdot d_{\mathrm{S}}+3\right) /\left(3 \cdot d_{\mathrm{S}}-3\right) .
\end{gathered}
$$

The maximum volumetric water content $H_{S}$ may be expressed as follows:

$$
\begin{gathered}
H_{\mathrm{S}}=1+(k-1) \cdot d_{\mathrm{B}} \approx 1-2 / 3 \cdot d_{\mathrm{B}} \\
\text { or } \quad H_{\mathrm{S}}=(1-1 / k) \cdot d_{\mathrm{S}}+1 / k \approx 3-2 d_{\mathrm{S}}
\end{gathered}
$$

Partitioning of water contained in wood between the cell wall and cell lumens for wood having different basic density and different saturation state is illustrated in Figure 1. The water bound in the cell wall cannot be used for physiological needs; therefore, free water content $F_{\mathrm{G}}$ computed as a difference between volumetric water content $H_{G}$ in green condition and water content bound in the cell wall $W_{F S P}$ is a more appropriate variable as we introduced in Longuetaud et al. (2017):

$$
F_{\mathrm{G}}=H_{\mathrm{G}}-w_{\mathrm{FSP}} \cdot d_{\mathrm{B}}
$$

The relative saturation of lumen in green wood specimens $\left(S_{G}\right)$ can be quantified as follows:

$$
S_{\mathrm{G}}=\left(H_{\mathrm{G}}-H_{\mathrm{FSP}}\right) /\left(H_{\mathrm{S}}-H_{\mathrm{FSP}}\right)
$$

where $H_{F S P}$ is volumetric water content at FSP.

The green and the saturated elastic moduli are the same $\left(E_{\mathrm{G}}=E_{\mathrm{S}}\right)$. As for any honeycomb cellular material, wood elastic modulus in the fibre direction is expected to be proportional to its density (Gibson \& Ashby, 1997):

$$
E_{\mathrm{G}}=E_{/ d} \cdot d_{\mathrm{B}}
$$

$E_{/ d} \cdot$ is referred to as "wood specific modulus" (Gibson \& Ashby, 1997; Niklas, 1993). We assume here that density reflects the amount of cell wall, by neglecting the contribution of non-structural material such as living cells' content and some extractive molecules located outside the cell wall. As the density of cell wall does not vary significantly among species and among wood types (Kellogg \& Wangaard, 1969), the specific modulus directly reflects the stiffness of the cell wall $\left(E_{\mathrm{cw}}\right)$ and $E_{/ \mathrm{d}} \approx E_{\mathrm{cw}} / 1.5$.

It is important to note that $E_{G}$, although being a property of green wood, is physically linked to basic density $d_{B}$ rather than to green density $d_{G}$ because $d_{G}$ is addition of mass of the mechanically efficient cell wall material and of the mechanically inert free water in lumen. Niklas and Spatz (2010) have found that $d_{G}$ measured at $50 \%$ moisture content was a good predictor of mechanical properties which is not surprising because $d_{50}$ is a multiple of $d_{B}$ : Equation 2 gives $d_{50}=1.5 d_{B}$. However, $50 \%$ of moisture content has no specific meaning regarding wood status in the living tree and conditioning wood at $50 \%$ moisture content is technically challenging. The proper mechanistic predictor of $E_{G}$ is $d_{B}$ since it represents the amount of supporting tissue in the unit of volume.

\section{5 | Statistical analyses}

We investigate three types of relationships from our data: (a) relationships between wood density and water status as expressed by Equations 3-7 (dataset 1); (b) relationships between physical parameters of wood in green condition and basic density (dataset 1) and (c) relationships between elastic modulus and density on dataset 2 (Equation 9). For each examined relationship, linear model was first fitted using the ordinary least square method implemented in "Im" function of the R software (R Core Team, 2017). Further, random effects (species for dataset 1 and nested levels species and individuals for dataset 2) were introduced using the "Imer" function of the "Ime4" package (Bates, Maechler, Bolker, \& Walker, 2015). Mixed-effect models were fitted by the restricted maximum-likelihood (REML) method. The selection of the best model fitted was based on Akaike's information criterion and likelihood ratio test for nested model ("ANOVA" function in R). For dataset 1, only random effect associated with

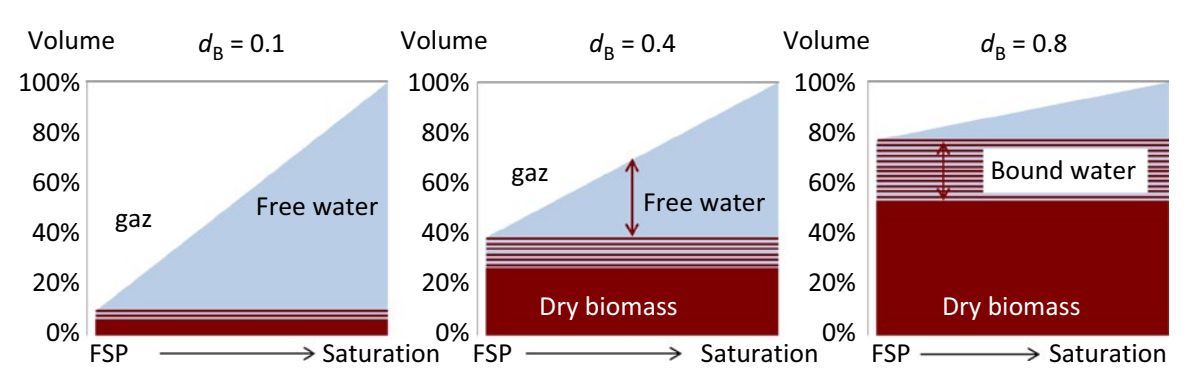

FIGURE 1 Illustration of theoretical variations of green density $d_{G}$ and moisture content $w_{G}$ within the range of volume available for water and air. As shown in Figure 1, the volume of voids $\left(H_{S}\right)$ decreases when basic density $d_{B}$ increases, can be filled only by air at the theoretical fibre saturation point and replaced by water at in the saturated situation. Three situations are explored: a very low basic density $d_{B}=0.1$ with plenty of space available for water and air, a very high one $d_{B}=0.8$ where voids for air or water are very limited and an intermediary common one of $d_{\mathrm{B}}=0.4$ 


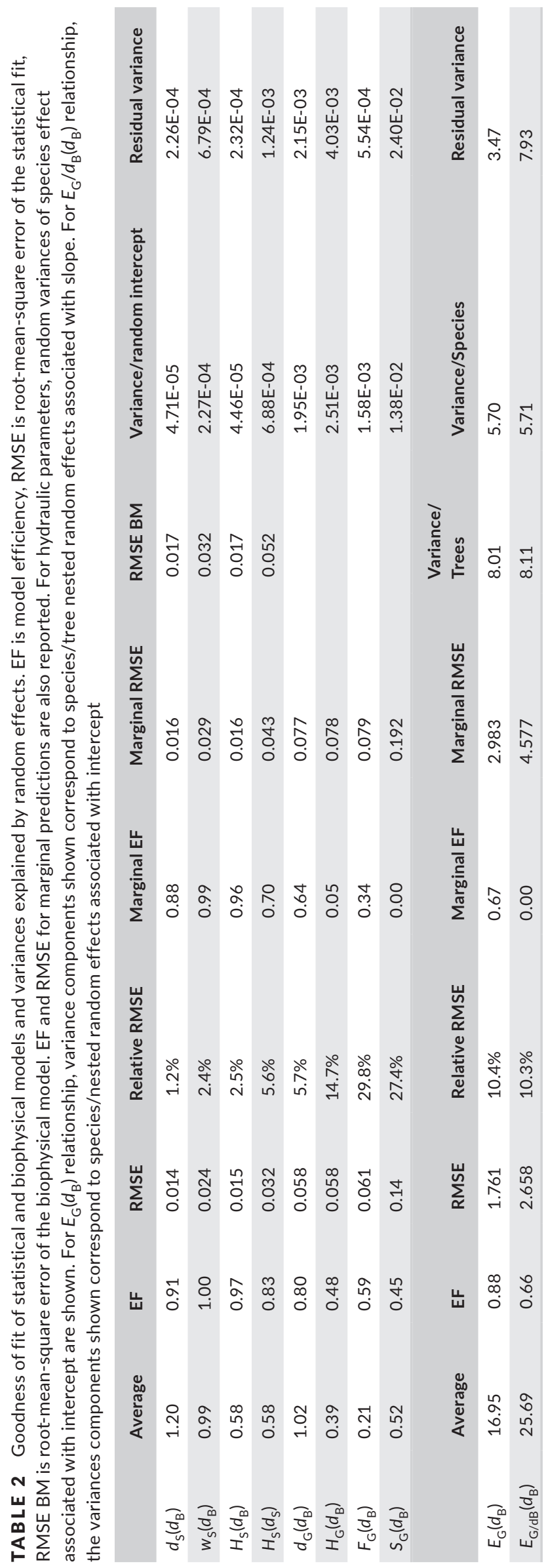

intercept was considered, as small number of specimens per species with limited intraspecific predictor range does not make it suitable for random slope model. Relationship between $w_{S}$ and $d_{B}$ was transformed to a linear form using $1 / d_{B}$ as a variable. For relationships estimating the green wood parameters, $d_{\mathrm{G}} \sim d_{\mathrm{B}}, F_{\mathrm{G}} \sim d_{\mathrm{B}}$, non-linear forms of model, namely, the second-order polynomial, the logarithmic and the power function for the relationship $d_{\mathrm{G}} \sim d_{\mathrm{B}}$ were tested using the "nlmer" function. In addition, the variance for these two relationships was not constant so weighted regression using the "VarExp" function was fitted. To examine whether the model parameter value was significantly different from zero or from the physical model parameter value, confidence intervals of the fixed parameters were investigated using the "confint" function, the level of confidence being set to 0.95 .

\section{3 | RESULTS}

As stated at the end of introduction, the better the physical model fits, the stronger the physical constraint it bears. A poorly fitted model means species or individuals are able to overturn laws of cellular material design, by adjusting the geometry of vessels to porosity, or by changing the cell wall mechanical properties with the amount of cell wall. Parameters of all empirical and physical models are summarized in Table 2.

\section{1 | Relationship between basic density and saturated density}

We found a linear relationship between saturated and basic density (Figure 2). Confidence interval of the slope parameter $k$ does not overlap the slope value of simplified physical model (0.33) but overlaps 0.36 , the $k$ value of a more complete model without the simplified assumption of volume additivity between water and cell wall material (see Supporting information Appendix S1). Slight overestimation of $d_{\mathrm{S}}$ as predicted from $d_{\mathrm{B}}$ by the physical model likely also comes from this simplification.

\section{2 | Relationship between density and maximal water content}

We found a strong inverse relationship between maximum moisture content $w_{S}$ and $d_{B}$ (Figure $3 a, E F>0.99, R M S E=0.024$ ), as predicted by Equation 4 . The $w_{S}$ values as modelled from $d_{S}$ (Equation 5) were overestimated, the model setting the upper bound of experimental values (Figure $3 b$ ). Further, we found that volumetric water content $H_{\mathrm{S}}$ scales linearly with both $d_{\mathrm{B}}$ and $d_{\mathrm{S}}$ as predicted by Equations 6 and 7 (Figure 3c,d). Note that relative RMSE is lower when $d_{B}$ is used as a predictor for $H_{S}$ (RMSE $=2.5 \%$ and $5.6 \%$ when $d_{S}$ is used). This is likely related to the weight of experimental error. Indeed, based on error propagation analysis, it can be shown that the prediction error for $H_{S}$ in response to measurement error on density is five times higher when based on $d_{\mathrm{S}}$ rather than on $d_{\mathrm{B}}$. 


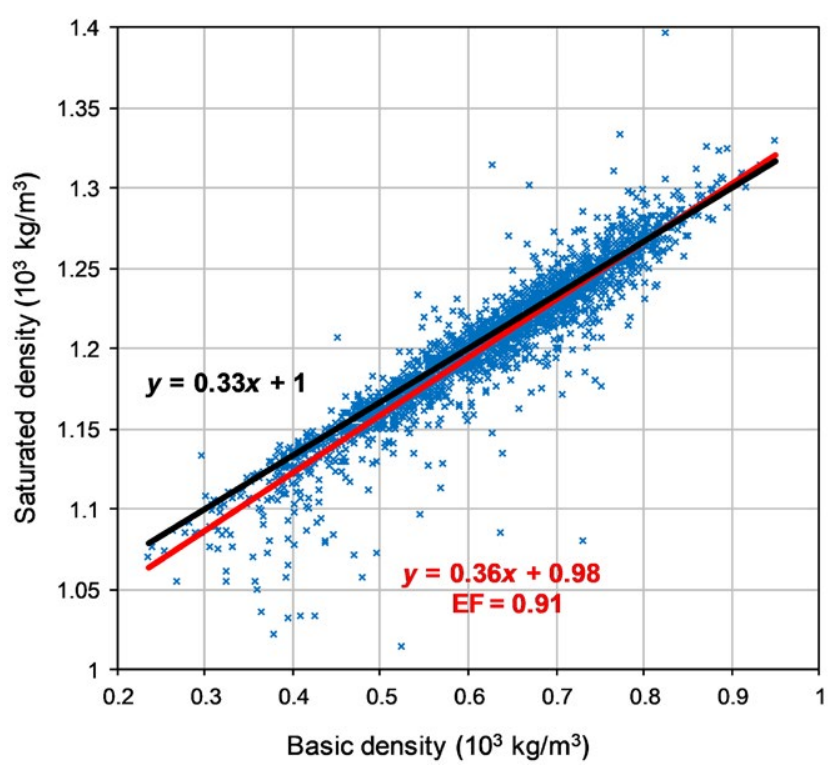

FIGURE 2 Relationship between saturated and basic density. Red line represents empirical fit, and black line corresponds to physical model (Equation 2)

\subsection{Relationships between basic density and physical parameters of green wood}

Relationship between $d_{\mathrm{G}}$ and $d_{\mathrm{B}}$ (Figuation 4a) was the best fitted by a logarithmic weighted regression with random effect associated with intercept. We found a negative linear fit with random effect associated with intercept between volumetric water content of green wood $H_{\mathrm{G}}$ and $d_{\mathrm{B}}$ (Figure $4 \mathrm{~b}$ ). Random effect significantly increased the model efficiency (Table 2), and the confidence interval of the slope parameter did not overlap zero and $p$-value was highly significant $(p<0.001$ ). Only 23 points out of 2,234 lie beyond the theoretical bounds set up by Equations 6 and 7 corresponding to FSP and saturated state, respectively. Free volumetric water content $F_{\mathrm{G}}$ scales with $d_{\mathrm{B}}$ as predicted by Equation 8 (Figure 4c), and the relationship was best fitted by a second-order polynomial weighted regression with null linear term. The slope of the $S_{G}-d_{B}$ linear model was not significant (confidence interval of the slope parameter overlapped zero, $p$-value $=0.74$ ) so random $y$-intercept model was fitted. Lumen saturation degree $S_{\mathrm{G}}$ covers all the potential range from close to $0 \%$ (FSP) to $100 \%$ (full saturation), $95 \%$ of data ranging between $15 \%$ and $88 \%$ and the average $S_{G}$ being $52 \%$ (Figure $4 d$ ). Note that a moisture content $w=50 \%$, a reference value used by Niklas and Spatz (2010), is physically impossible for woods with basic density larger than $0.86 \times 10^{3} \mathrm{~kg} / \mathrm{m}^{3}$.

\section{4 | Relationship between mechanical properties and density}

Relationship between elastic modulus $E_{\mathrm{G}}$ and $d_{\mathrm{B}}$ was best fitted by a linear regression without intercept with nested random effects species/tree associated with the slope (Figure 5a). The form of the statistical fit followed theoretical prediction (Equation 10). Variance components analysis of random effects shows that $47 \%$ of the random variance was explained by tree effect and $37 \%$ by species effect (Table 2).

Slope of the linear relationship between wood specific modulus $E_{/ \mathrm{d}}$ and $d_{\mathrm{B}}$ was not statistically significant, and its confidence interval overlapped zero for both models, with and without random effects associated with the intercept ( $p$-value equal to 0.18 and 0.08 , respectively). Therefore, we fitted $y$-intercept model with nested random effects species/tree associated with the intercept. As shown in Table 2, tree and species effects explained, respectively, $37 \%$ and $26 \%$ of the random variance. Figure $5 \mathrm{~b}$ includes a compilation of previously reported green wood data (see figure legend for details) and shows wide range of variation of $E_{/ d}$ (from 20 to $30 \mathrm{GPa} \cdot \mathrm{m}^{3} / \mathrm{kg}$ ).

\section{DISCUSSION}

\subsection{Due to cellular nature of wood material, dried matter content, namely, basic density, is strongly linked to maximal water content $w_{\mathrm{s}}$ or $\mathrm{H}_{\mathrm{s}}$}

The use of inherently linked parameters artificially inflates the weight of the considered variable. Moreover, if the physical relationship is non-linear as between $w_{S}$ and $d_{B}$, usual multivariate analyses will fail in detecting the redundancy and will treat this non-linearity as a source of variability. As basic density is physically linked to fully saturated wood properties $d_{S}, w_{S}$ or $H_{S}$ (Equations 3-5, Figures 2 and 3), we advocate the use of a single wood trait, namely, basic density, to represent these four parameters in multivariate analyses of wood traits for ecological studies as in Chave et al. (2009), Baraloto, Paine, et al., 2010; Baraloto, Timothy Paine, et al., 2010 and Fortunel, Ruelle, Beauchêne, Fine, and Baraloto (2014).

\subsection{The amount of free water available for physiological needs, namely, $F_{\mathrm{G}}$, slightly increases in light wood species with faster growth}

Green wood traits $\left(d_{\mathrm{G}}, w_{\mathrm{G}}, H_{\mathrm{G}}\right.$ and $\left.S_{\mathrm{G}}\right)$ are not mechanistically related to basic density because they depend on the relative proportion of gas and water in the lumens. This proportion varies with many parameters such as environmental condition, daytime, season, rain events and ontogeny (Barnard et al., 2011; Hao, Wheeler, Holbrook, \& Goldstein, 2013; Pineda-Garcia, Paz, \& Meinzer, 2013; Scholz et al., 2008); however, the magnitude of temporal variation does not exceed 10\% (Hao et al., 2013).

Negative relationships observed between free water content and basic density (Table 3 ) indicate that light wood species store higher amount of available water per unit of wood volume. We may question the biological reason for this. In angiosperms, light wood is associated with larger vessels (Hietz, Rosner, Hietz-Seifert, \& Wright, 2017; Zanne 

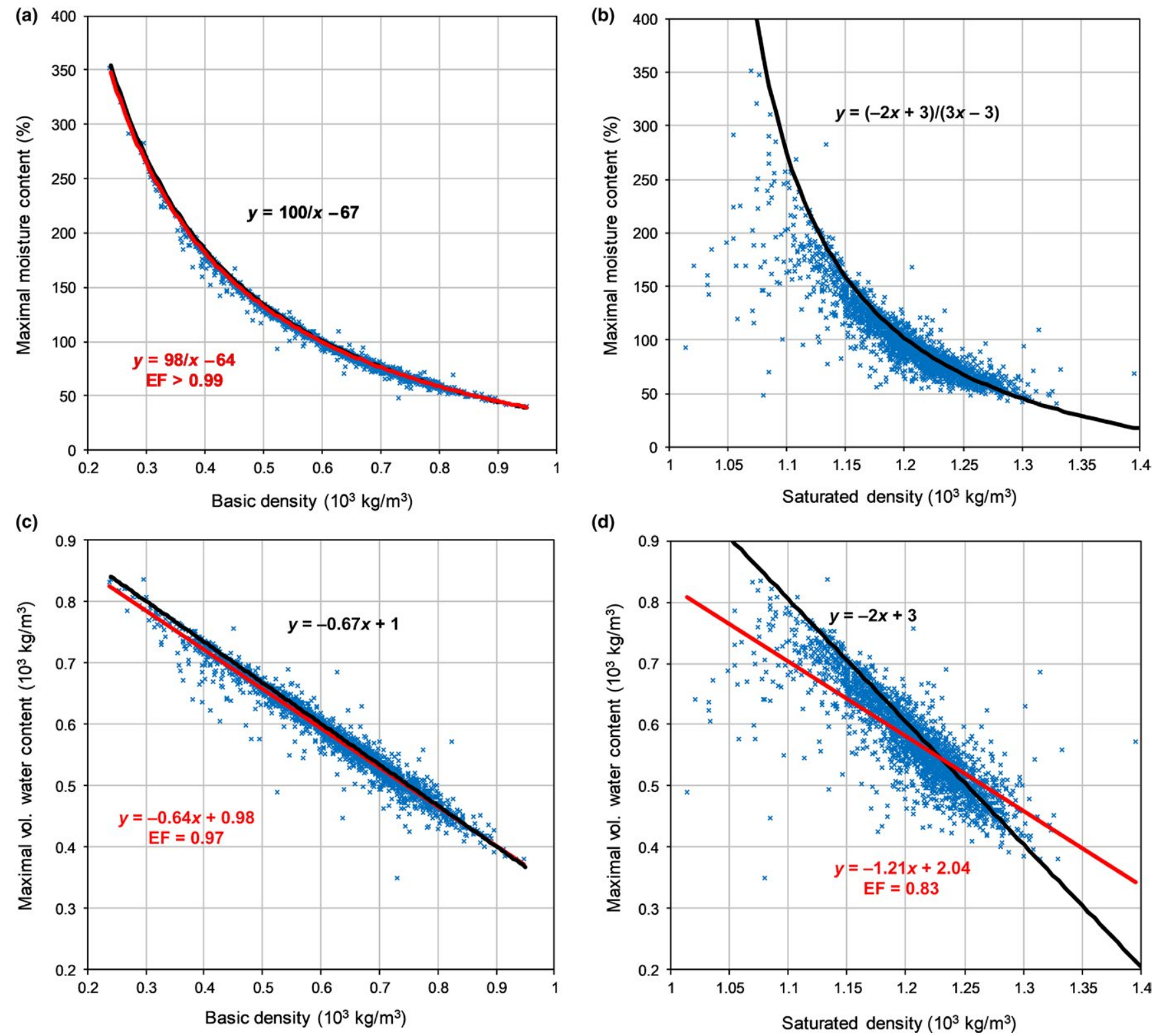

FIGURE 3 Relationships between (a) maximum moisture content and basic density; (b) maximum moisture content and saturated density, (c) maximum volumetric water content and basic density and (d) maximum volumetric water content and saturated density. Red curve represents empirical fit, and black curve corresponds to physical model (Equations 3, 6-8)

et al., 2010) that is not a physical necessity (low density can be easily obtained from a large number of small vessels) but an adaptation of light wood species to fast growth because large vessels enhance hydraulic conductance for a given basic density (Lachenbruch \& McCulloh, 2014). Large vessels can also retain water more easily so the adapted higher conductance of less dense wood is physically associated with a higher capacity to store water although ecological requirements would have suggested that dense wood species, more adapted to drought, should tend to increase their water storage capacity (Holbrook, 1995). On the other hand, species with low density wood and, presumably, higher transpiration rates, may more rely on release of stored water to constrain transpiration-induced fluctuation in xylem tension (Goldstein et al., 1998) compared to species with denser wood that rely primarily on xylem structural features to avoid embolism (Meinzer, Johnson, Lachenbruch, McCulloh, \& Woodruff, 2009).

\subsection{Relative proportion of water and gas in green wood lumens $S_{G}$ represents an axis of wood traits orthogonal to basic density}

Wide variety in the use of available porosity for water or gas storage (Figure $4 d$ ) suggests that $S_{\mathrm{G}}$ is a good candidate trait constituting an axis of functional diversity independent of $d_{\mathrm{B}}$. Our dataset and reanalysed literature data (Gartner et al., 2004; Poorter, 2008) come from a zone without a drought constraint which is consistent with very weak or non-significant correlation found between $S_{\mathrm{G}}$ and $d_{\mathrm{B}}$ 


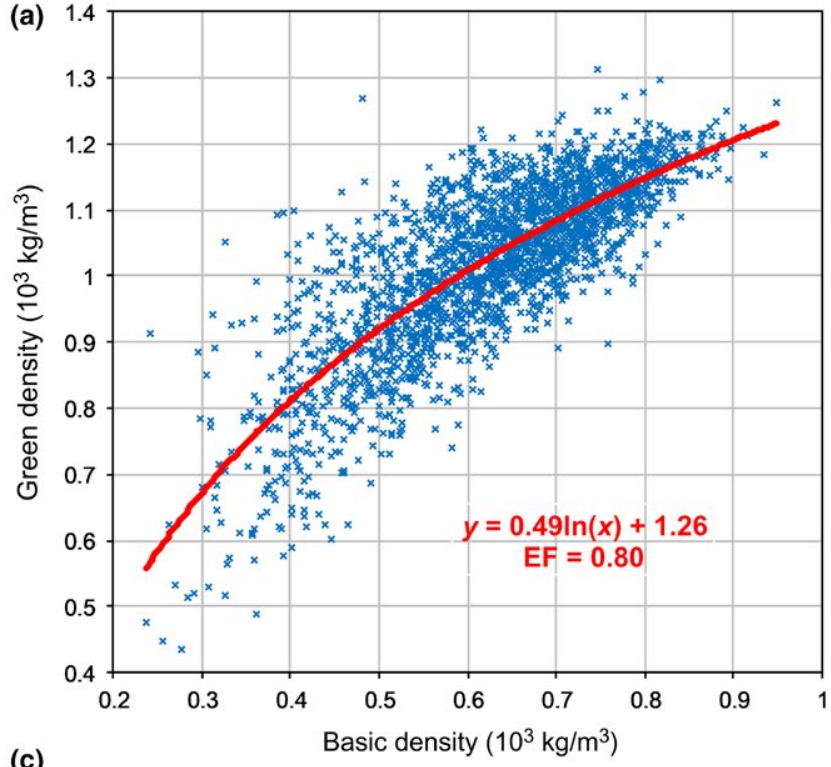

(c)

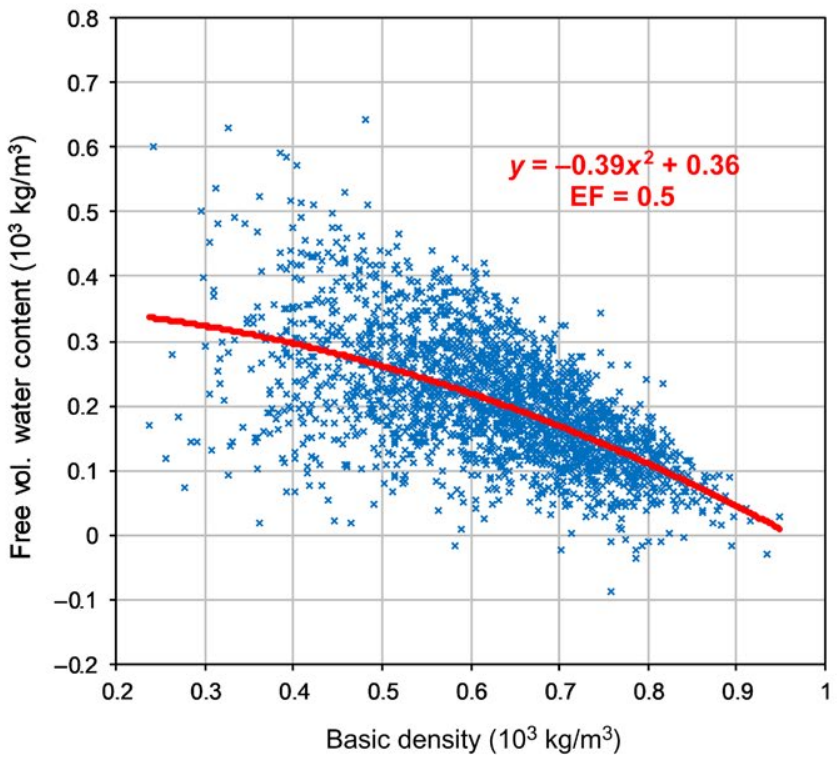

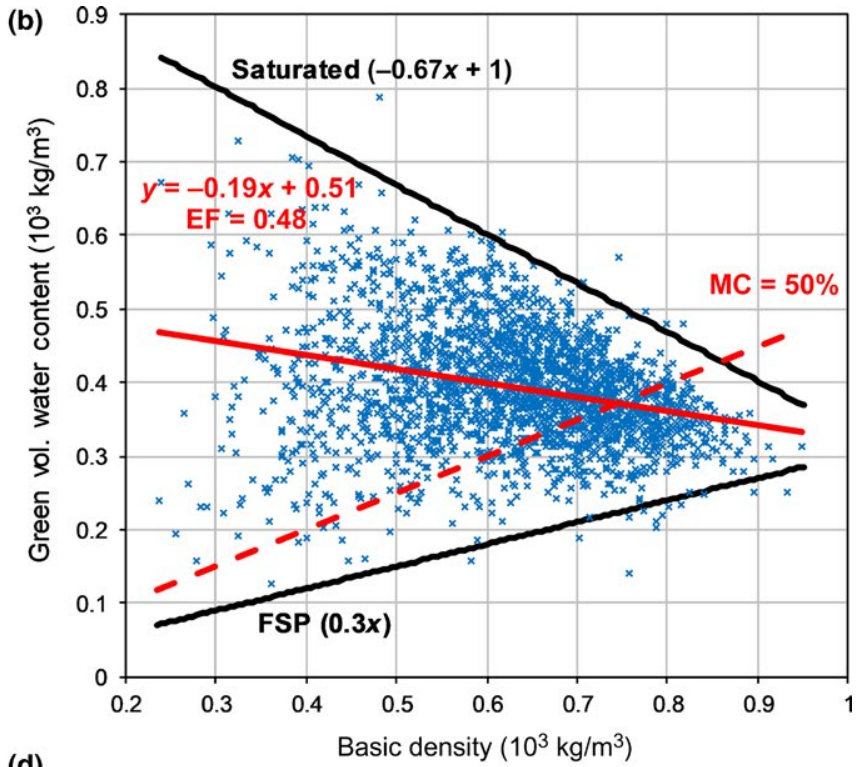

(d)

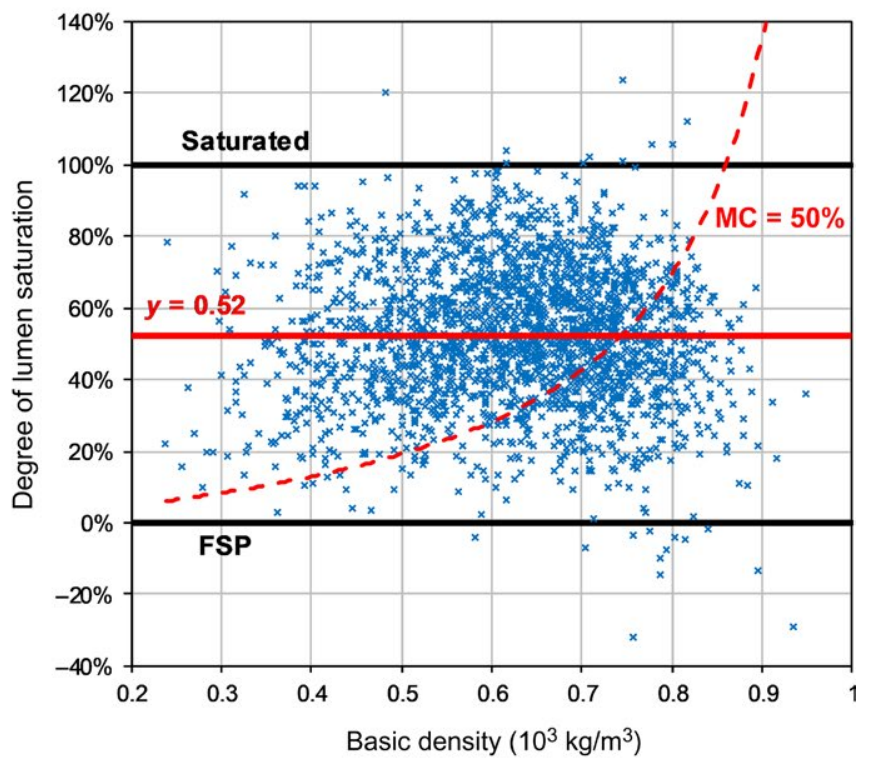

FIG URE 4 Relationships between (a) green and basic density; (b) green volumetric water content and basic density; (c) free volumetric water content and basic density and (d) degree of lumen saturation and basic density. In all graphs, red lines represent empirical fit. Black lines in Figure $4 \mathrm{~b}$ correspond to the physical relationship expected at fibre saturation point (FSP) and in fully saturated condition. Black lines in Figure 4d correspond to the FSP and full saturation condition, and dashed red line corresponds to moisture content of $50 \%$. Solid black lines indicate the theoretical upper bound corresponding to the saturated state (Equation 5) and lower bound corresponding to the FSP. FSP is taken as $30 \%$ moisture content. FSP usually ranges between $28 \%$ and $32 \%$ with exceptionally low values (17\%-25\%) in wood of high extractives contents (Popper, Niemz \& Torres, 2006)

(Table 3). However, associations between $S_{G}$ and $d_{B}$ can be expected for ecological reasons. For instance, a higher $S_{G}$ would be expected in high density wood to maintain the amount of free water although less available space in lumens; alternatively, if low wood density is an adaptation to produce higher capacity for water storage, then a negative association between $d_{\mathrm{B}}$ and $S_{\mathrm{G}}$ should be expected. Water storage capacity is definitely an interesting trait to study in the current context of adaptation of forest composition to climate change. Benefit of low lumen saturation raises the question of the role of gas in the living tree. As stated by Gartner et al. (2004), oxygen is necessary for the respiration of living cells such as parenchyma and has therefore a physiological role. Correlation between amount of parenchyma and wood gas content has never been examined to our knowledge but could provide some clue. Another potential benefit of replacing lumen water by gas is increasing mechanical stability by decreasing stem weight. Gartner et al. (2004) showed that this benefit was negligible regarding resistance to wind forces. The benefit regarding self-stability has never been quantified to our knowledge, but is a good candidate since the critical buckling tree height scales with the inverse square root of stem mass (Jaouen, Almeras, Coutand, \& Fournier, 2007), which, for a given basic density, directly depends on the amount of gas it contains. 


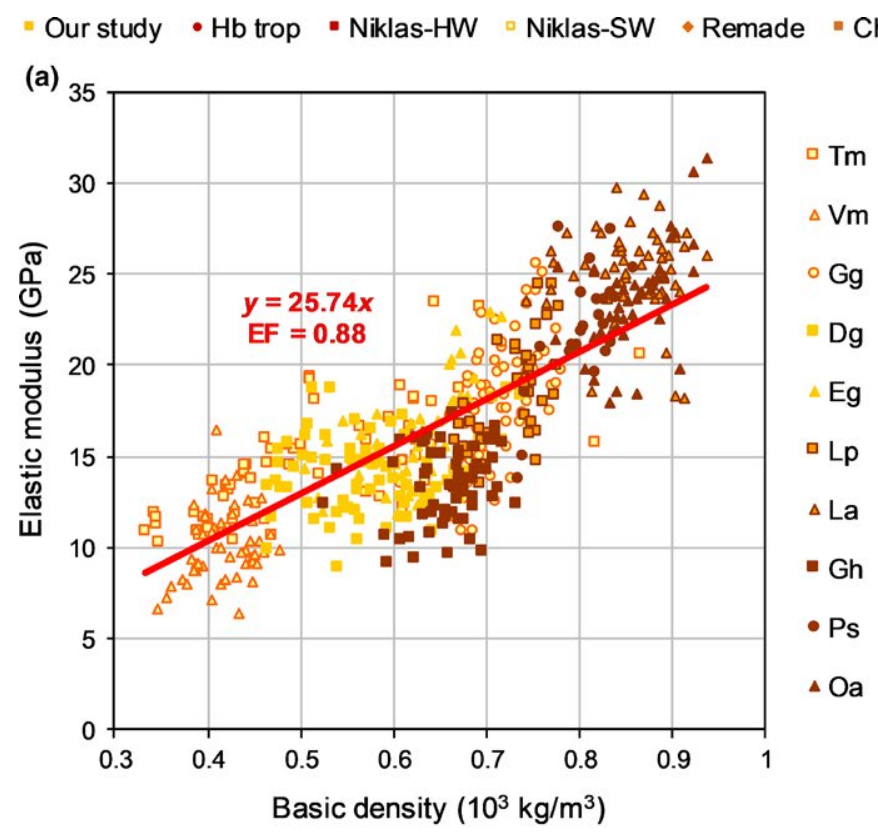

Chudhoff $\square$ Our study aMcLean-OW aMcLean - TW • Hb temp HW

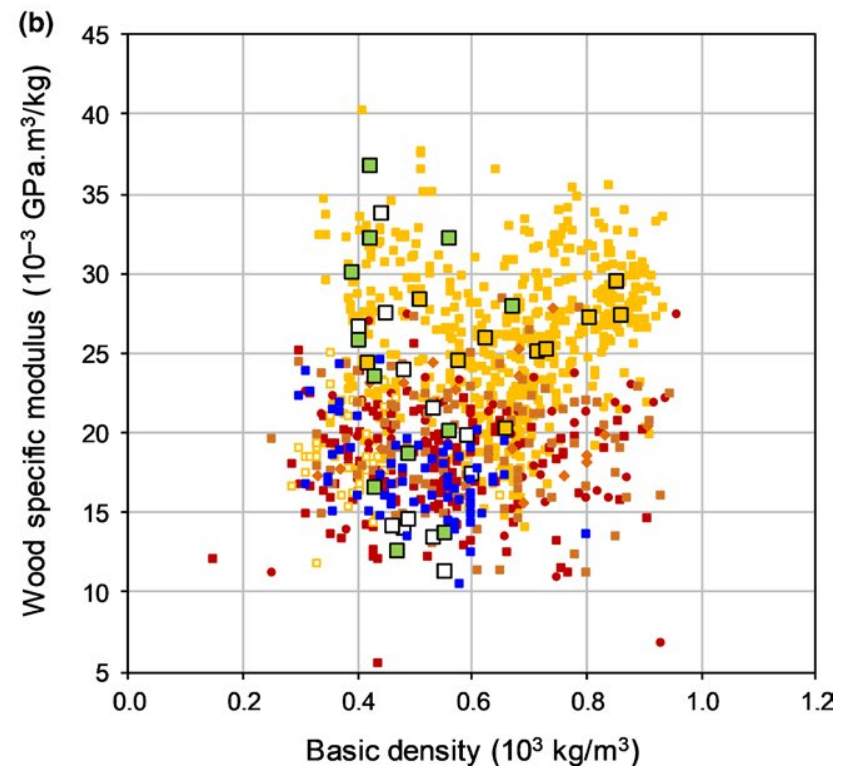

FIGURE 5 Relationship between (a) elastic modulus and basic density; (b) wood specific modulus and basic density for our study (average values per species) and different literature sources ${ }^{\left({ }^{1}\right)}$ (Forest Product Laboratory 2010); ${ }^{(2)}$ (Niklas \& Spatz, 2010); ${ }^{(3)}$ (Chudnoff 1979);

${ }^{(4)}$ database of Brazilian wood properties available online (http://www.remade.com.br) and McLean et al. (2012). Vm: Virola michelii Heckel; Dg: Dicorynia guianensis Amsh.; Eg: Eperua grandiflora (Aubl.) Benth.; Lp: Lecythis persistens Sagot; La: Licania alba (Bernoulli) Cuatrec.; Oa: Oxandra asbeckii (Pulle) R.E. Fries; Gg: Goupia glabra Aubl.; Tm: Tachigali melionii (Harms) Zarucchi \& Herend.; Gh: Gustavia hexapetala (Aubl.) J.E. Smith; Ps: Pogonophora schomburgkiana Miers ex Benth.; temp: temperate; trop: tropical; HW: hardwoods; SW: softwoods; OW: opposite wood; TW: tension wood. Red line corresponds to empirical fit

\section{4 | Wood mechanical properties: part explained by density and information carried by residual variability related to cell wall variation}

Proportional relationship between elastic modulus and density, well established in the wood material scientist community (Evans \& Ilic, 2001; Yang \& Evans, 2003) and validated on large interspecific studies in the context of ecology (Chave et al., 2009; van Gelder, Poorter, \& Sterck, 2006; Niklas \& Spatz, 2010) was confirmed also in our study (Figure $5 \mathrm{a}$ ). High scatter is likely due to variation of parameters affecting cell wall properties such as microfibril angle or chemical composition (Salmen \& Burgert, 2009) known to largely vary with ontogeny (Lachenbruch et al., 2011), growth or site condition (Medhurst et al., 2012; Wimmer, Downes, \& Evans, 2002) and reaction wood occurrence (Hori, Suzuki, Kamiyama, \& Sugiyama, 2003; Yoshida, Ohta, Yamamoto, \& Okuyama, 2002).

Our results together with a compilation of literature data show that green wood specific modulus $E_{/ d}$ is highly variable between and within species and independent of $d_{B}$ (Figure 5b, Table 4) except for temperate hardwoods for which weak but significant negative $E$, $d^{-} d_{\mathrm{B}}$ linear relationship ( $p<0.01, R^{2}=0.27$, Table 4) was observed, revealing that lighter wood has developed stiffer cell walls. Despite differences in geographical origin and phylogenic classification, average values for all datasets are very close except for the present study and the study by McLean, Arnould, Beauchene, and Clair (2012) (Table 4). Although this difference may by partly attributed to the experimental method (the resonance method is known to slightly overestimate the elastic modulus when compared to static bending test (Brancheriau \& Bailleres, 2002; Haines, Leban, \& Herbe, 1996), we assume that higher values of wood specific modulus are not a methodological artefact but originates in the sampling. Actually, other studies do not deal with sapling stage of development in tropical understory, where competition for light foraging is severe, tree trunks extremely slender, easily deformable, and close to their self-supporting limit (Jaouen et al., 2007), so that a higher specific modulus could be a great advantage for both growth and survival as suggested by McLean et al. (2011).

Positive or negative associations between $E_{/ d}$ and $d_{B}$ may be expected in some specifically constrained environments or at a particular location inside the tree. As stated by Read, Evans, Sanson, Kerr, and Jaffre (2011), Cerberiopsis candelabra trees growing in cyclone-prone environments combine (a) the low density wood associated with fast growth in diameter and then, higher tree bending strength, despite lower wood modulus of rupture (see Larjavaara and Muller-Landau (2010) for an accurate discussion about why weaker wood of lower density make stronger trees) and (b) high cell wall stiffness $E_{/ d}$ to better resist bending wind loads. While the benefit of high $E_{/ d}$ is clearly to achieve high stiffness for a given investment in biomass, production of wood with low $E_{/ d}$ may result from a trade-off with other mechanical functions. For example, the occurrence of compression wood in gymnosperms is generally associated with large microfibril angle and low cellulose content (Donaldson, Grace, \& Downes, 2004). These features are necessary for this wood to perform its function, that is, generate the righting movement that enables a gravitropic correction 


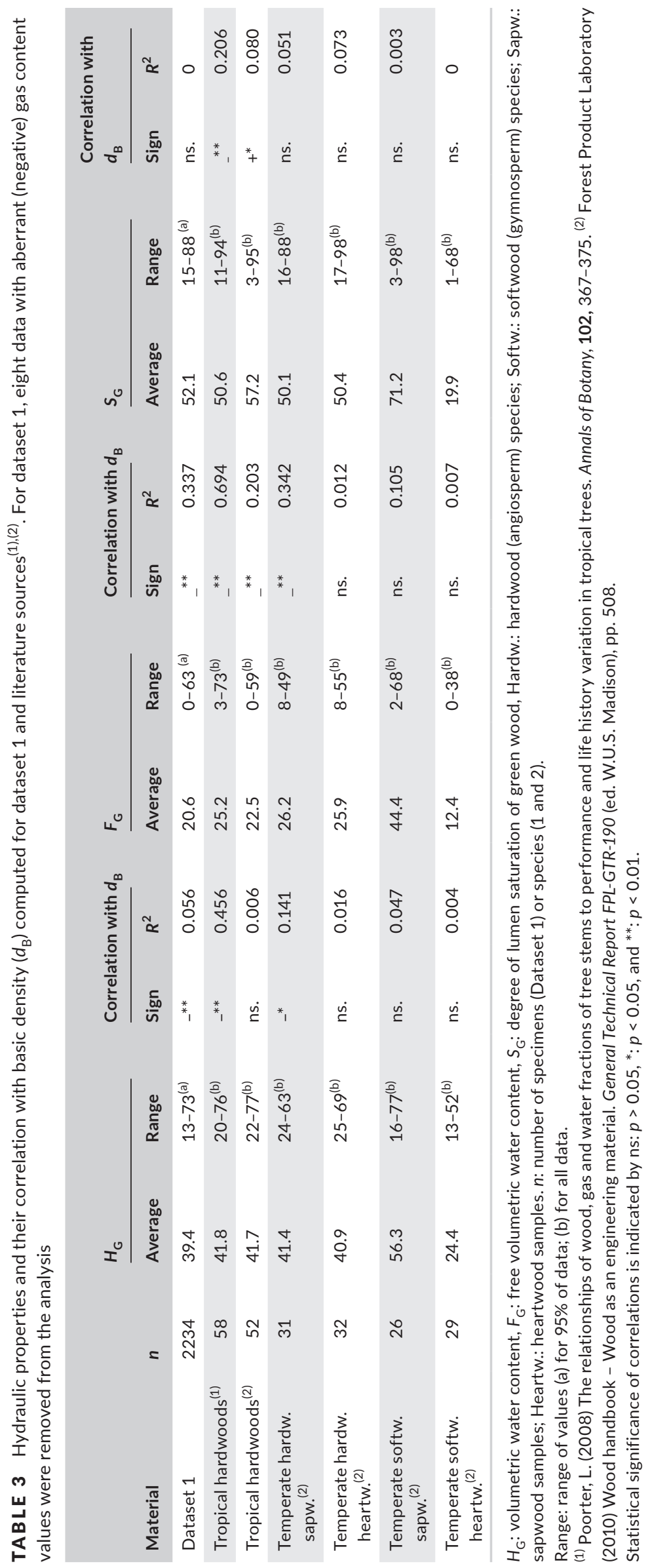


TAB L E 4 Wood specific modulus $\left(E_{/ d}\right)$ and its correlation with basic density $\left(d_{\mathrm{B}}\right)$ computed for dataset 2 and different literature

\begin{tabular}{|c|c|c|c|c|c|c|}
\hline & $N$ & Method & $E_{/ d}$ & $S D$ & $R^{2}$ & Sign \\
\hline Temperate softwoods ${ }^{(1)}$ & 69 & SB & 20.9 & 3.28 & 0.048 & ns \\
\hline Temperate softwoods ${ }^{(2)}$ & 37 & SB & 18.6 & 2.66 & 0.002 & ns \\
\hline Tropical hardwoods ${ }^{(1)}$ & 67 & SB & 19.5 & 3.62 & 0.000 & ns \\
\hline Tropical hardwoods ${ }^{(3)}$ & 103 & SB & 19.5 & 3.68 & 0.010 & ns \\
\hline Tropical hardwoods ${ }^{(4)}$ & 20 & SB & 20.2 & 3.46 & 0.010 & ns \\
\hline Dataset 2 & 10 & $\mathrm{R}$ & 25.8 & 2.58 & 0.130 & ns \\
\hline
\end{tabular}

Method of measurement is SB: static bending; R: resonance measurement; ST: quasi-static tensile test on a DMA device. OW: opposite wood; TW: tension wood; N: number of species; SD: standard deviation.

${ }^{(1)}$ Forest Product Laboratory (2010) Wood handbook - Wood as an engineering material. General Technical Report FPL-GTR-190 (ed. W.U.S. Madison), pp. 508.; ${ }^{(2)}$ Niklas, K.J. \& Spatz, H.-C. (2010) Worldwide correlations of mechanical properties and green wood density. American Journal of Botany, 97 , 1587-1594.; ${ }^{(3)}$ Chudnoff, M. (1979) Tropical timbers of the world.; ${ }^{(4)}$ database of Brazilian wood properties available online (http://www.remade.com.br) and McLean McLean, J.P., Arnould, O., Beauchene, J. \& Clair, B. (2012) The effect of the G-layer on the viscoelastic properties of tropical hardwoods. Annals of Forest Science, 69, 399-408.

Statistical significance of correlations is indicated by ns. $(p>0.05),{ }^{*}(p<0.05)$ and ${ }^{* *}(p<0.01)$.

(Almeras \& Fournier, 2009), but they also induce a lower specific modulus. Here, the positioning along the $E_{/ d}$ axis reveals a trade-off between two mechanical functions of wood: providing the stem with high stiffness or providing it with a motor system. Other typical examples of occurrence of wood with low specific modulus are juvenile wood (Lachenbruch et al., 2011) found in young stem or in the core of older stems, and so-called flexure wood (Telewski, 1989) sometimes found in trees growing in windy conditions. Both these woods have a large microfibril angle, reducing their stiffness, but also probably increasing their deformability, that is, their capacity to undergo large deformations without damage. A large wood deformability increases the overall flexibility of the stem and allows for the reduction of winds loads (or other external loads such as falling trees) by geometric reconfiguration. In this instance, the positioning along the $E_{/ d}$ axis expresses a trade-off between mechanical stress-resistant and stressavoidant strategies. Data that we have about mechanical properties of wood are mostly limited to elastic modulus, and very little is known about the green wood behaviour in rupture although this parameter is essential for the tree survival to bending loads. If a low value of wood specific modulus may be useful in small trees or large trees relying on the stress-avoidant strategy against wind, high modulus of rupture is presumably always useful for woody plants.

\section{5 | Ecological significance of mechanistic and statistical independences among wood traits: advocating the use of physically independent traits}

Based on physical relationships between basic density and other wood traits, we advocate the use of three mechanistically independent traits $\left(d_{\mathrm{B}}, S_{\mathrm{G}}\right.$ and $\left.E_{/ \mathrm{d}}\right)$ as relevant wood traits to investigate the spectrum of life strategies and functional diversity of trees.

The method we used to define $E_{/ d}$ from $E_{G}$ and $d_{B}$ from mechanistic models of cellular material could be extended to any mechanical or hydraulic property. In cellular solids, density is a basic trait, and theoretical scaling laws of tissue properties vs. density can be derived from material physics (Gibson \& Ashby, 1997). The residual variation from these theoretical scaling laws observed in nature along ecological gradients bring relevant information about species adaptation even if no direct data about tissue anatomy or cell wall ultrastructure are available. For example, as the resistance to cavitation P50 has become a common hydraulic trait measured with quite high throughput and organized in large databases (Choat et al., 2012), it would be interesting to design a robust physical model of this trait combining approaches of Hacke, Sperry, Pockman, Davis, and McCulloh (2001) and current developments at the cell wall level (Tixier et al., 2014) to infer theoretically what is the underlying information born by the residual variation of the moderate correlation observed between P50 and $d_{\mathrm{B}}$ (Westoby \& Wright, 2006). Many recent works in wood ecology take inspiration from previous works of wood anatomists (Carlquist, 2001) to interpret variations of wood structural traits as functional adaptations (Beeckman, 2016). Environmental and phylogenetic variations of vessel frequencies and size (Lachenbruch \& McCulloh, 2014; Zanne et al., 2010), axial and radial parenchyma (Zheng \& Martínez-Cabrera, 2013), microfibril angle (Read et al., 2011) are then discussed. Generalizing the way physiologists use prediction of maximum conductance by the fourth power of conduit diameters, using biophysical framework to design metrics of functionally significant and theoretically independent 
traits, instead of analysing roughly the whole set of traits measured, is likely to contribute to identification of growth strategies among the large functional diversity of woods.

\section{ACKNOWLEDGEMENTS}

This work was supported by a grant overseen by the French National Research Agency to the Woodiversity (ANR-05-BDIV-0012-04) and Bridge (ANR-06-BDIV-0004) projects. The UMR1092 and EcoFoG are supported by a grant overseen by the French National Research Agency (ANR) as part of the "Investissements d'Avenir" program (ANR-11-LABX-0002-01, Lab of Excellence ARBRE) and (CEBA, ref. ANR-10-LABX-25-01), respectively. Authors would also like to thank the late $A$. Thibaut for help with experimental measurements performed in the framework of Bridge project.

\section{AUTHORS' CONTRIBUTIONS}

J.D., B.C. and J.B. collected the data; J.D. and T.A. analysed the data; J.D., T.A. and M.F. led the writing of the manuscript. All authors contributed critically to the drafts and gave final approval for publication.

\section{DATA ACCESSIBILITY}

Data available from the Dryad Digital Repository: https://doi. org/10.5061/dryad.t775334 (Dlouhá et al., 2018).

\section{ORCID}

Jana Dlouhá (iD http://orcid.org/0000-0002-9282-639X

\section{REFERENCES}

Almeras, T., \& Fournier, M. (2009). Biomechanical design and long-term stability of trees: Morphological and wood traits involved in the balance between weight increase and the gravitropic reaction. Journal of Theoretical Biology, 256, 370-381. https://doi.org/10.1016/j. jtbi.2008.10.011

Baraloto, C., Paine, C. E. T., Patino, S., Bonal, D., Herault, B., \& Chave, J. (2010). Functional trait variation and sampling strategies in species-rich plant communities. Functio, 24(1), 208-216. https://doi. org/10.1111/j.1365-2435.2009.01600.x

Baraloto, C., Timothy Paine, C. E., Poorter, L., Beauchene, J., Bonal, D., Domenach, A.-M., ... Chave, J. (2010). Decoupled leaf and stem economics in rain forest trees. Ecology Letters, 13(11), 1338-1347. https://doi.org/10.1111/j.1461-0248.2010.01517.x

Barnard, D. M., Meinzer, F. C., Lachenbruch, B., McCulloh, K. A., Johnson, D. M., \& Woodruff, D. R. (2011). Climate-related trends in sapwood biophysical properties in two conifers: Avoidance of hydraulic dysfunction through coordinated adjustments in xylem efficiency, safety and capacitance. Plant Cell and Environment, 34, 643-654. https://doi.org/10.1111/j.1365-3040.2010.02269.x

Barnett, J., \& Jeronimidis, G. (2003). Wood quality and its biological basis. New York: Wiley-Blackwell.

Bastin, J.-F., Fayolle, A., Tarelkin, Y., Van den Bulcke, J., de Haulleville, T., Mortier, F., ... De Cannière, C. (2015). Wood specific gravity variations and biomass of central african tree species: The simple choice of the outer wood. PLoS One, 10, e0142146. https://doi.org/10.1371/journal.pone.0142146

Bates, D., Maechler, M., Bolker, B., \& Walker, S. (2015). Fitting linear mixed-effects models using Ime4. Journal of Statistic Software, 67(1), 1-48. https://doi.org/10.18637/jss.v067.i01

Beeckman, H. (2016). Wood anatomy and trait-based ecology. lawa Journal, 37, 127-151. https://doi.org/10.1163/22941932-20160127

Brancheriau, L., \& Bailleres, H. (2002). Natural vibration analysis of clear wooden beams: A theoretical review. Wood Science and Technology, 36, 347-365. https://doi.org/10.1007/s00226-002-0143-7

Brémaud, I. (2006). Diversity of woods used or usable in musical instruments making. Mechanic of materials. Montpellier, France: University of Montpellier II.

Brémaud, I., El Kaïm, Y., Guibal, D., Minato, K., Thibaut, B., \& Gril, J. (2012). Characterisation and categorisation of the diversity in viscoelastic vibrational properties between 98 wood types. Annals of Forest Science, 69(3), 373-386. https://doi.org/10.1007/s13595-011-0166-z

Carlquist, S. (2001). Comparative wood anatomy: Systematic, ecological, and evolutionary aspects of dicotyledon wood. Springer series in wood science. Berlin, New York: Springer-Verlag. https://doi. org/10.1007/978-3-662-04578-7

Chave, J., Coomes, D., Jansen, S., Lewis, S. L., Swenson, N. G., \& Zanne, A. E. (2009). Towards a worldwide wood economics spectrum. Ecology Letters, 12, 351-366. https://doi. $\operatorname{org} / 10.1111 /$ j.1461-0248.2009.01285.x

Choat, B., Jansen, S., Brodribb, T. J., Cochard, H., Delzon, S., Bhaskar, R., ... Zanne, A. E. (2012). Global convergence in the vulnerability of forests to drought. Nature, 491, 752-755. https://doi.org/10.1038/ nature11688

Dlouhá, J., Alméras, T., Beauchêne, J., Clair, B., \& Fournier, M. (2018). Data from: Biophysical dependences among functional wood traits. Dryad Digital Repository, https://doi.org/10.5061/dryad.t775334

Dlouha, J., Almeras, T., \& Clair, B. (2012). Representativeness of wood biomechanical properties measured after storage in different conditions. Trees-Structure and Function, 26, 695-703. https://doi. org/10.1007/s00468-011-0636-9

Donaldson, L. A., Grace, J., \& Downes, G. M. (2004). Within-tree variation in anatomical properties of compression wood in radiata pine. lawa Journal, 25, 253-271. https://doi.org/10.1163/22941932-90000364

Evans, R., \& Ilic, J. (2001). Rapid prediction of wood stiffness from microfibril angle and density. Forest Products Journal, 51, 53-57.

Fortunel, C., Fine, P. V. A., \& Baraloto, C. (2012). Leaf, stem and root tissue strategies across 758 Neotropical tree species. Functional Ecology, 26, 1153-1161. https://doi.org/10.1111/j.1365-2435.2012.02020.x

Fortunel, C., Ruelle, J., Beauchêne, J., Fine, P. V. A., \& Baraloto, C. (2014). Wood specific gravity and anatomy of branches and roots in 113 Amazonian rainforest tree species across environmental gradients. New Phytologist, 202, 79-94. https://doi.org/10.1111/ nph.12632

Fournier, M., Dlouha, J., Jaouen, G., \& Almeras, T. (2013). Integrative biomechanics for tree ecology: Beyond wood density and strength. Journal of Experimental Botany, 64, 4793-4815. https://doi. org/10.1093/jxb/ert279

Gartner, B. L., Moore, J. R., \& Gardiner, B. A. (2004). Gas in stems: Abundance and potential consequences for tree biomechanics. Tree Physiology, 24, 1239-1250. https://doi.org/10.1093/ treephys/24.11.1239

van Gelder, H. A., Poorter, L., \& Sterck, F. J. (2006). Wood mechanics, allometry, and life-history variation in a tropical rain forest tree community. New Phytologist, 171, 367-378. https://doi. org/10.1111/j.1469-8137.2006.01757.x

Gibson, L. J., \& Ashby, M. F. (1997). Cellular solids. Structure and properties (2ème ed.). Cambridge, UK: Cambridge University Press. https://doi. org/10.1017/СВО9781139878326 
Goldstein, G., Andrade, J. L., Meinzer, F. C., Holbrook, N. M., Cavelier, J., Jackson, P., \& Celis, A. (1998). Stem water storage and diurnal patterns of water use in tropical forest canopy trees. Plant Cell and Environment, 21(4), 397-406. https://doi.org/10.1046/j.1365-3040.1998.00273.x

Gourlet-Fleury, S., Guehl, J.-M., \& Laroussinie, O. (2004). Ecology and management of a neotropical rainforest: Lessons drawn from Paracou, a long-term experimental research site in French Guiana. Paris, France: Elsevier.

Hacke, U. G., Sperry, J. S., Pockman, W. T., Davis, S. D., \& McCulloh, K. A. (2001). Trends in wood density and structure are linked to prevention of xylem implosion by negative pressure. Oecologia, 126, 457-461. https://doi.org/10.1007/s004420100628

Haines, D. W., Leban, J. M., \& Herbe, C. (1996). Determination of Young's modulus for spruce, fir and isotropic materials by the resonance flexure method with comparisons to static flexure and other dynamic methods. Wood Science and Technology, 30, 253-263.

Hao, G. Y., Wheeler, J. K., Holbrook, N. M., \& Goldstein, G. (2013). Investigating xylem embolism formation, refilling and water storage in tree trunks using frequency domain reflectometry. Journal of Experimental Botany, 64, 2321-2332. https://doi.org/10.1093/jxb/ert090

Hietz, P., Rosner, S., Hietz-Seifert, U., \& Wright, S. J. (2017). Wood traits related to size and life history of trees in a Panamanian rainforest. New Phytologist, 213, 170-180. https://doi.org/10.1111/nph.14123

Holbrook, N. M. (1995). Stem water storage. In B. Gartner (Ed.), Plant Stems (pp. 151-174). San Diego, CA: Elsevier. https://doi.org/10.1016/ B978-012276460-8/50009-6

Hori, R., Suzuki, H., Kamiyama, T., \& Sugiyama, J. (2003). Variation of microfibril angles and chemical composition: Implication for functional properties. Journal of Materials Science Letters, 22, 963-966. https:// doi.org/10.1023/A:1024604728118

Jaouen, G., Almeras, T., Coutand, C., \& Fournier, M. (2007). How to determine sapling buckling risk with only a few measurements. American Journal of Botany, 94, 1583-1593. https://doi.org/10.3732/ ajb.94.10.1583

Kellogg, R. M., \& Wangaard, F. F. (1969). Variation in the cell-wall density of wood. Wood and Fiber Science, 1, 180-204.

King, D. A., Davies, S. J., Tan, S., \& Noor, N. S. M. (2006). The role of wood density and stem support costs in the growth and mortality of tropical trees. Journal of Ecology, 94, 670-680. https://doi. org/10.1111/j.1365-2745.2006.01112.x

Kunstler, G., Falster, D., Coomes, D. A., Hui, F., Kooyman, R. M., Laughlin, D. C., ... Westoby, M. (2016). Plant functional traits have globally consistent effects on competition. Nature, 529, 204-U174. https://doi. org/10.1038/nature16476

Lachenbruch, B., \& McCulloh, K. A. (2014). Traits, properties, and performance: How woody plants combine hydraulic and mechanical functions in a cell, tissue, or whole plant. New Phytologist, 204, 747-764. https://doi.org/10.1111/nph.13035

Lachenbruch, B., Moore, J. R., \& Evans, R. (2011). Radial variation in wood structure and function in woody plants, and hypotheses for its occurrence. In F. C. Meinzer, B. Lachenbruch, \& T. E. Dawson (Eds.), Sizeand age-related changes in tree structure and function (pp. 121-164). Netherlands: Springer. https://doi.org/10.1007/978-94-007-1242-3

Larjavaara, M., \& Muller-Landau, H. C. (2010). Rethinking the value of high wood density. Functional Ecology, 24, 701-705. https://doi. org/10.1111/j.1365-2435.2010.01698.x

Longuetaud, F., Mothe, F., Santenoise, P., Diop, N., Dlouha, J., Fournier, M., \& Deleuze, C. (2017). Patterns of within-stem variations in wood specific gravity and water content for five temperate tree species. Annals of Forest Science, 74(3), 64. https://doi.org/10.1007/ s13595-017-0657-7

McLean, J. P., Arnould, O., Beauchene, J., \& Clair, B. (2012). The effect of the G-layer on the viscoelastic properties of tropical hardwoods. Annals of Forest Science, 69, 399-408. https://doi.org/10.1007/ s13595-011-0164-1
McLean, J. P., Zhang, T., Bardet, S., Beauchene, J., Thibaut, A., Clair, B., $\&$ Thibaut, B. (2011). The decreasing radial wood stiffness pattern of some tropical trees growing in the primary forest is reversed and increases when they are grown in a plantation. Annals of Forest Science, 68, 681-688. https://doi.org/10.1007/s13595-011-0085-z

Medhurst, J., Downes, G., Ottenschlaeger, M., Harwood, C., Evans, R., \& Beadle, C. (2012). Intra-specific competition and the radial development of wood density, microfibril angle and modulus of elasticity in plantation-grown Eucalyptus nitens. Trees-Structure and Function, 26, 1771-1780. https://doi.org/10.1007/s00468-012-0746-z

Meinzer, F. C., Johnson, D. M., Lachenbruch, B., McCulloh, K. A., \& Woodruff, D. R. (2009). Xylem hydraulic safety margins in woody plants: Coordination of stomatal control of xylem tension with hydraulic capacitance. Functional Ecology, 23, 922-930. https://doi. org/10.1111/j.1365-2435.2009.01577.x

Moles, A. T. (2018). Being John Harper: Using evolutionary ideas to improve understanding of global patterns in plant traits. Journal of Ecology, 106, 1-18. https://doi.org/10.1111/1365-2745.12887

Niklas, K. J. (1993). Influence of tissue density-specific mechanical properties on the scaling of plant height. Annals of Botany, 72, 173-179. https://doi.org/10.1006/anbo.1993.1096

Niklas, K. J., \& Spatz, H.-C. (2010). Worldwide correlations of mechanical properties and green wood density. American Journal of Botany, 97, 1587-1594. https://doi.org/10.3732/ajb.1000150

Niklas, K. J., \& Spatz, H.-C. (2012). Mechanical properties of wood disproportionately increase with increasing density. American Journal of Botany, 99, 169-170. https://doi.org/10.3732/ajb.1100567

Nogueira, E. M., Fearnside, P. M., \& Nelson, B. W. (2008). Normalization of wood density in biomass estimates of Amazon forests. Forest Ecology and Management, 256, 990-996. https://doi.org/10.1016/j. foreco.2008.06.001

Osazuwa-Peters, O. L., Wright, S. J., \& Zanne, A. E. (2017). Linking wood traits to vital rates in tropical rainforest trees: Insights from comparing sapling and adult wood. American Journal of Botany, 104, 14641473. https://doi.org/10.3732/ajb.1700242

Osunkoya, O. O., Omar-Ali, K., Amit, N., Dayan, J., Daud, D. S., \& Sheng, T. K. (2007). Comparative height-crown allometry and mechanical design in 22 tree species of Kuala Belalong rainforest, Brunei, Borneo. American Journal of Botany, 94, 1951-1962. https://doi.org/10.3732/ ajb.94.12.1951

Pineda-Garcia, F., Paz, H., \& Meinzer, F. C. (2013). Drought resistance in early and late secondary successional species from a tropical dry forest: The interplay between xylem resistance to embolism, sapwood water storage and leaf shedding. Plant Cell and Environment, 36, 405418. https://doi.org/10.1111/j.1365-3040.2012.02582.x

Poorter, L. (2008). The relationships of wood-, gas- and water fractions of tree stems to performance and life history variation in tropical trees. Annals of Botany, 102, 367-375. https://doi.org/10.1093/aob/ mcn103

Poorter, L., McDonald, I., Alarcon, A., Fichtler, E., Licona, J. C., PenaClaros, M., ... Sass-Klaassen, U. (2010). The importance of wood traits and hydraulic conductance for the performance and life history strategies of 42 rainforest tree species. New Phytologist, 185, 481-492. https://doi.org/10.1111/j.1469-8137.2009.03092.x

Popper, R., Niemz, P., \& Torres, M. (2006). Einfluss des Extraktstoffanteils ausgewählter fremdländischer Holzarten auf deren Gleichgewichtsfeuchte. Holz als Roh- und Werkstoff, 64, 491-496. https://doi.org/10.1007/s00107-006-0132-x

R Core Team. (2017). R: A Language and Environment for Statistical Computing. Vienna, Austria: R Core Team. https://doi.org/10.1038/ sj.hdy. 6800737

Read, J., Evans, R., Sanson, G. D., Kerr, S., \& Jaffre, T. (2011). Wood properties and trunk allometry of co-occurring rainforest canopy trees in a cyclone-prone environment. American Journal of Botany, 98, 17621772. https://doi.org/10.3732/ajb.1100080 
Richardson, S. J., Allen, R. B., Buxton, R. P., Easdale, T. A., Hurst, J. M.,

Morse, C. W., ... Peltzer, D. A. (2013). Intraspecific relationships among wood density, leaf structural traits and environment in four co-occurring species of Nothofagus in New Zealand. PLoS One, 8, e58878. https://doi.org/10.1371/journal.pone.0058878

Ruelle, J., Clair, B., Beauchene, J., Prevost, M. F., \& Fournier, M. (2006). Tension wood and opposite wood in 21 tropical rain forest species 2. Comparison of some anatomical and ultrastructural criteria. lawa Journal, 27, 341-376. https://doi.org/10.1163/22941932-90000159

Russo, S. E., Jenkins, K. L., Wiser, S. K., Uriarte, M., Duncan, R. P., \& Coomes, D. A. (2010). Interspecific relationships among growth, mortality and xylem traits of woody species from New Zealand. Functional Ecology, 24, 253-262. https://doi.org/10.1111/j.1365-2435.2009.01670.x

Salmen, L., \& Burgert, I. (2009). Cell wall features with regard to mechanical performance. A review COST Action E35 2004-2008: Wood machining - micromechanics and fracture. Holzforschung, 63, 121-129. https://doi.org/10.1515/hf.2009.011

Sarmiento, C., Patiño, S., Paine, C. E. T., Beauchêne, J., Thibaut, A., \& Baraloto, C. (2011). Within-individual variation of trunk and branch xylem density in tropical trees. American Journal of Botany, 98, 140149. https://doi.org/10.3732/ajb.1000034

Scholz, F. G., Bucci, S. J., Goldstein, G., Meinzer, F. C., Franco, A. C., \& Miralles-Wilhelm, F. (2008). Temporal dynamics of stem expansion and contraction in savanna trees: Withdrawal and recharge of stored water. Tree Physiology, 28, 469-480. https://doi.org/10.1093/ treephys/28.3.469

Telewski, F. W. (1989). Structure and function of flexure wood in Abies fraseri. Tree Physiology, 5, 113-121. https://doi.org/10.1093/ treephys/5.1.113

Tixier, A., Herbette, S., Jansen, S., Capron, M., Tordjeman, P., Cochard, H., \& Badel, E. (2014). Modelling the mechanical behaviour of pit membranes in bordered pits with respect to cavitation resistance in angiosperms. Annals of Botany, 114, 325-334. https://doi.org/10.1093/ aob/mcu109

Westoby, M., \& Wright, I. J. (2006). Land-plant ecology on the basis of functional traits. Trends in Ecology \& Evolution, 21, 261-268. https:// doi.org/10.1016/j.tree.2006.02.004

Wimmer, R., Downes, G. M., \& Evans, R. (2002). Temporal variation of microfibril angle in Eucalyptus nitens grown in different irrigation regimes. Tree Physiology, 22, 449-457. https://doi.org/10.1093/ treephys/22.7.449

Yang, J. L., \& Evans, R. (2003). Prediction of MOE of eucalypt wood from microfibril angle and density. Holz Als Roh-Und Werkstoff, 61, 449452. https://doi.org/10.1007/s00107-003-0424-3

Yoshida, M., Ohta, H., Yamamoto, H., \& Okuyama, T. (2002). Tensile growth stress and lignin distribution in the cell walls of yellow poplar, Liriodendron tulipifera Linn. Trees, 16, 457-464. https://doi. org/10.1007/s00468-002-0186-2

Zanne, A. E., Westoby, M., Falster, D. S., Ackerly, D. D., Loarie, S. R., Arnold, S. E. J., \& Coomes, D. A. (2010). Angiosperm wood structure: Global patterns in vessel anatomy and their relation to wood density and potential conductivity. American Journal of Botany, 97, 207-215. https://doi.org/10.3732/ajb.0900178

Zheng, J., \& Martínez-Cabrera, H. I. (2013). Wood anatomical correlates with theoretical conductivity and wood density across China: Evolutionary evidence of the functional differentiation of axial and radial parenchyma. Annals of Botany, 112, 927-935. https://doi. org/10.1093/aob/mct153

Ziemińska, K., Westoby, M., \& Wright, I. J. (2015). Broad anatomical variation within a narrow wood density range-A study of twig wood across 69 Australian angiosperms. PLoS One, 10(4), e0124892. Retrieved from https://doi.org/10.1371/journal.pone.0124892 